\title{
Review Laporan Keuangan Baznas Kabupaten Magelang dengan PSAK 109
}

\author{
Fuad Yanuar'), Yassirly Amriya ${ }^{2)}$, Nuwun Priyono ${ }^{3)}$ \\ ${ }^{1,2}$ Ekonomi Islam, STAI Al-Husain \\ ${ }^{3} \mathrm{FE}$, Universitas Tidar \\ *Email korespondensi: fyarc86@gmail.com
}

\begin{abstract}
The National Amil Zakat Agency (BAZNAS) is the official and only body formed by the government based on Presidential Decree No. 8 of 2001 which has the duties and functions of collecting and distributing zakat, infaq, and alms (ZIS) at the national level. BAZNAS is declared as a non-structural government institution that is independent and is responsible to the President through the Minister of Religion. Thus, BAZNAS together with the Government is responsible for overseeing the management of zakat which is based on: Islamic law, trust, expediency, justice, legal certainty, integrated and accountability. PSAK 109 is one of the financial standards set for the amil zakat body which is expected to realize reporting uniformity and simplicity of recording. So that the public can read the zakat manager's accounting reports and oversee their management so that muzzaki believes in channeling zakat through the amil zakat body. This condition occurs in BAZNAS Magelang Regency which has presented the report well. PSAK 109 consists of five components, namely the cash flow statement report, balance sheet (statement of financial position), report on changes in funds, statement of assets under management and notes to financial statements. This research uses applied research with a qualitative approach. This research was conducted in four stages, namely data collection conducted by interviews and documentation, data reduction, data presentation, and drawing conclusions. The results of this study indicate that the financial recording system at BAZNAS Magelang Regency is in accordance with PSAK 109.
\end{abstract}

Keywords: Amil Zakat Institution, BAZNAS, Financial Statements, PSAK 109

Saran sitasi: Yanuar, F., Amriya, Y., \& Priyono, N. (2020). Review Laporan Keuangan Baznas Kabupaten Magelang dengan PSAK 109. Jurnal Akuntansi dan Pajak, 21 (1), 164-175. doi:http://dx.doi.org/10.29040/jap.v21i1.1161

DOI: $\underline{\text { http://dx.doi.org/10.29040/jap.v21i1.1161 }}$

\section{PENDAHULUAN}

Indonesia merupakan negara dengan mayoritas penduduknya beragama Islam. Pada tahun 2020 penduduk Islam di Indonesia diperkirakan mencapai 229, 62 juta jiwa. Fakta ini tentu menyebabkan banyaknya masyarakat muslim menjalankan syari'ah Islam dalam kehidupan sosial-ekonomi. Wujud dari kehidupan sosial-ekonomi dalam syariat Islam adalah memberikan solusi untuk mengatasi permasalahan kemiskinan dengan berzakat. Di Indonesia Zakat diatur dalam Undang-undang No. 23 Tahun 2011 tentang Pengelolaan Zakat. Undang-undang tersebut berisi tentang pengelolaan zakat agar terorganisir dengan baik, transparan dan professional dan dilakukan oleh amil resmi yang ditunjuk oleh pemerintah, baik Lembaga Amil Zakat (LAZ) maupun Badan Amil Zakat (BAZ). BAZ (Badan
Amil Zakat) merupakan lemabaga pengelola zakat yang didirikan atas usul Kementrian Agama dan disetujui oleh Presiden. Tugas BAZ sendiri hanya untuk mengelola atau mendistribusikan menyelenggarakan tugas administratif dan teknis pengumpulan, pendistribusian dan pendayagunaan zakat, dan menyelenggarakan bimbingan dibidang pengolahan pengumpulan, pendistribusian dan pendayagunaan zakat.

Usaha pemerintah untuk mencapai tujuan pengelolaan zakat adalah membentuk Badan Amil Zakat Nasional (BAZNAS). Badan Amil Zakat Nasional (BAZNAS) merupakan badan resmi dan satu-satunya yang dibentuk oleh pemerintah berdasarkan Keputusan Presiden RI No. 8 Tahun 2001 yang memiliki tugas dan fungsi menghimpun dan menyalurkan zakat, infaq, dan sedekah (ZIS) 
pada tingkat nasional. Lahirnya Undang-Undang Nomor 23 Tahun 2011 tentang Pengelolaan Zakat semakin mengukuhkan peran BAZNAS sebagai lembaga yang berwenang melakukan pengelolaan zakat secara nasional. Dalam UU tersebut, BAZNAS dinyatakan sebagai lembaga pemerintah nonstruktural yang bersifat mandiri dan bertanggung jawab kepada Presiden melalui Menteri Agama. Dengan demikian, BAZNAS bersama Pemerintah bertanggung jawab untuk mengawal pengelolaan zakat yang berasaskan: syariat Islam, amanah, kemanfaatan, keadilan, kepastian hukum, terintegrasi dan akuntabilitas.

Pengelolaan zakat adalah kegiatan perencanaan, pelaksanaan, dan pengkoordinasian dalam pengumpulan, pendistribusian, dan pendayagunaan zakat. Pengelolaan zakat tentunya harus berdasarkan syariat Islam dengan prinsip amanah, kemanfaatan, keadilan, kepastian hukum, terintegrasi dan akuntabilitas. Suatu lembaga dapat dikatakan baik apabila lembaga tersebut memiliki sistem administrasi dan tata kelola lembaga yang baik. Sebuah tata kelola dapat dikatakan baik apabila lembaga tersebut bersifat transparan dan akuntabel dalam pengumpulan, penghimpunan serta pendistribusian dana zakatnya, sehingga pelaporan dana zakat yang ada pada lembaga pengelola zakat dapat dipertanggungjawabkan. Hal ini dirasa mampu untuk meningkatkan kepercayaan masyarakat dalam menyalurkan dana zakatnya kepada lembaga tersebut.

Laporan keuangan seharusnya informatif dan dapat dibandingkan antara laporan keuangan lembaga pengelola zakat satu dengan lembaga pengelola zakat yang lain. Laporan keuangan amil menurut PSAK 109 adalah laporan posisi keuangan (neraca), laporan perubahan dana, laporan perubahan aset kelolaan, laporan arus kas dan catatan atas laporan keuangan. Neraca dan perubahan dana untuk organisasi zakat, infak, dan sedekah ini merupakan gabungan dari dua dana tersebut, yaitu dana zakat dan dana sedekah, sedangkan laporan perubahan posisi keuangan dan catatan atas laporan keuangan perlu ditambahkan sehingga menjadi laporan keuangan yang menyeluruh yang menggambarkan kondisi keuangan organisasi pengelola zakat. Dalam catatan ini menjelaskan mengenai kebijakan-kebijakan akuntansi dan prosedur yang diterapkan oleh organisasi yang bersangkutan sehingga diperoleh angka-angka dalam laporan keuangan tersebut.
PSAK 109 Tentang Akuntasi Zakat dan Infak/sedekah diharapkan dapat mewujudkan keseragaman pelaporan, dan kesederhanaan pencatatan. Sehingga publik dapat membaca laporan akuntansi pengelola zakat serta mengawasi pengelolaannya. Selain itu penerapan PSAK 109 ini juga bertujuan memastikan bahwa organisasi pengelola zakat telah memakai prinsip-prinsip syariah, dan seberapa jauh OPZ memiliki tingkat kepatuhan menerapkannya. PSAK 109 yang mengatur akuntansi zakat dan infak/sedekah, di dalamnya termuat definisi-definisi, pengakuan dan pengukuran, penyajian, serta pengungkapan hal-hal yang terkait dengan kebijakan penyaluran hingga operasionalisasi zakat dan infak/sedekah.

Laporan keuangan merupakan usaha pertanggung jawaban lembaga atau organisasi yang obyektif, Baznas juga sebagai organisasi yang mengelola dana zakat infak dan sedekah dari masyarakat maupun pegawai negeri sudah harus membuat laporan keuangan yang sesuai standar akuntansi yaitu PSAK 109.

Dalam penyusunan keuangan harus menaati prinsip akuntasi yang belaku umum saat ini. Prinsip akuntansi yang digunakan organisasi pengelola zakat yaitu pernyataan standar akuntansi keuangan (PSAK). PSAK berfungsi sebagai standar agar dapat dijadikan acuan dan pedoman dalam penyusunan laporan keuangan. Dengan adanya tuntutan untuk menerapkan akuntabilitas dan transparasi menjadikan organisasi pengelola zakat harus membuat laporankeuangan sesuai dengan aturan yang berlaku. Dalam hal ini yang menjadipedoman akuntansi zakat, dan infak/sedekah adalah PSAK 109. Dengandiberlakukannya PSAK 109 maka setiap organisasi pengelolaan zakat akanmemiliki standar pelaporan yang sama dan bersifat mengikat sehingga dapatdilakukan perbandingan antar lembaga zakat. Dalam PSAK 109 juga memiliki konsep dalam pengakuan, pengukuran , penyajian, dan pengungkapan. Konsep-konsep ini akan menjelaskan bagaiamana unsur-unsur laporan keuangan harus diakui, diukur, disajikan, dan diungkapkan oleh Lembaga Amil Zakat, Infak/Sedekah.Pengakuan adalah pencatatan suatu jumlah rupiah (kos) ke dalam sistem akuntansi sehingga jumlah tersebut akan mempengaruhi suatu pos dan terefleksi dalam laporan keuangan. Jadi, pengkauan berhubungan dengan masalah apakah suatu transaski dicatat (dijurnal) atau tidak. 


\section{Jurnal Akuntansi dan Pajak, 21 (01), 2020, 166}

Berdasarkan PSAK 109 tentang Akuntansi Zakat, Infak/Sedekah, komponen laporan keuangan amil yang lengkap terdiri dari:

\section{a. Laporan posisi keuangan}

Entitas amil menyajikan pos-pos dalam laporan posisi keuangan dengan memperhatikan ketentuan dalam PSAK terkait, yang mencakup, tetapi tidak terbatas pada:

1) Aset

a) Kas dan setara kas

Kas dan setara kas adalah uang tunai yang paling likuid sehingga pos ini biasanya ditempatkan pada urutan teratas dari aset. Yang termasuk dalam kas adalah seluruh alat pembayaran yang dapat digunakan dengan segera seperti uang kertas, uang logam, dan saldo rekening giro di bank. Menurut PSAK, setara kas adalah investasi yang sifatnya likuid, berjangka pendek, dan dengan cepat dapat dijadikan kas dalam jumlah tertentu tanpa menghadapi resiko perubahan nilai yang signifikan.

b) Piutang

Piutang adalah salah satu jenis transaksi akuntansi yang mengurusi penagihan konsumen yang berhutang pada seseorang, suatu perusahaan, atau suatu organisasi untuk barang dan layanan yang telah diberikan kepada konsumen tersebut. Hal ini biasanya dilakukan dengan membuat tagihan dan mengirimkan tagihan tersebut kepada konsumen yang akan dibayar dalam suatu tenggat waktu yang disebut termin kredit pembayaran.

c) Aset tetap dan akumulasi penyusutan

Aset tetap mempunyai nilai yang semakin berkurang dari suatu periode ke periode berikutnya. Dengan demikian nilai aset tetap akan menjadi turun apabila sudah dipakai atau digunakan dalam periode tertentu. Nilai aktiva tetap akan menjadi berkurang karena adanya pemakaian aktiva tetap tersebut sehingga dalam akuntansi dikenal adanya penyusutan aset tetap. Penyusutan atau depresiasi adalah pengalokasian harga perolehan dari suatu aset tetap karena adanya penurunan nilai aset tetap tersebut.
2) Liabilitas

a) Biaya yang masih harus dibayar

Biaya-biaya yang harus dibayarkan oleh perusahaan kepada pihak lain atau jasa-jasa yang telah dilakukan oleh pihak lain demi kepentingan perusahaan. Biaya tersebut sudah merupakan kewajiban perusahaan untuk membayarnya, namun belum dibayarkan oleh perusahaan, sehingga masih merupakan utang atau kewajiban yang harus ditanggung oleh perusahaan untuk melunasinya.

b) Kewajiban imbalan kerja

Imbalan kerja adalah seluruh bentuk imbalan yang diberikan suatu entitas dalam pertukaran atas jasa yang diberikan oleh pekerja atau untuk pemutusan kontrak kerja. Jadi kewajiban imbalan kerja adalah kewajiban yang timbul akibat adanya imbalan kerja.

c) Saldo dana

(1) Dana zakat

Saldo dana zakat yaitu jumlah saldo akhir dana zakat untuk tiap periode. Jumlah tersebut didapatkan dari penerimaan dana zakat, dikurangi penyaluran dana zakat dan dijumlahkan dengan saldo awal dana zakat.

(2) Dana infak/sedekah

Saldo dana infak/sedekah yaitu jumlah saldo akhir dana infak/sedekah untuk tiap periode. Jumlah tersebut didapatkan dari penerimaan dana infak/sedekah, dikurangi penyaluran dana infak/sedekah dan dijumlahkan dengan saldo awal dana infak/sedekah.

(3) Dana amil

Saldo dana amil yaitu jumlah saldo akhir dana amil untuk tiap periode. Jumlah tersebut didapatkan dari penerimaan dana amil, dikurangi penggunaan dana amil dan dijumlahkan dengan saldo awal dana amil.

(4) Dana nonhalal

Saldo dana nonhalal yaitu jumlah saldo akhir dana nonhalal untuk tiap periode. Jumlah tersebut didapatkan dari penerimaan dana nonhalal, dikurangi penyaluran dana nonhalal dan dijumlahkan dengan saldo awal dana nonhalal. 


\section{b. Laporan Perubahan Dana}

Laporan perubahan dana menggambarkan peningkatan atau penurunan aktiva bersih atau kekayaan selama periode tertentu. Entitas amil menyajikan laporan perubahan dana zakat, dana infak/sedekah, dan dana amil. Penyajian laporan perubahan dana mencakup, tetapi tidak terbatas pada, pos-pos berikut:

1) Dana Zakat

a) Penerimaan dana zakat

Penerimaan dana zakat yaitu jumlah dana yang diterima dari muzakki, baik individu, entitas ataupun UPZ.

b) Penyaluran dana zakat

(1) Amil, yaitu zakat yang disalurkan kepada amil apabila digunakan untuk pengelolaan amil.

(2) Mustahiq non amil, penyaluran zakat untuk non amil.

c) Saldo awal dana zakat, yaitu jumlah dana zakat pada saat awal periode.

d) Saldo akhir dana zakat, yaitu jumlah dana zakat pada saat akhir periode.

2) Dana infak/sedekah

a) Penerimaan dana infak/sedekah:

(1) Infak/sedekah terikat (muqayyadah), yaitu dana infak/sedekah yang pada saat penerimaan diberikan batasan-batasan tertentu terhadap penggunaan dana tersebut.

(2) Infak/sedekah tidak terikat (mutlaqah), yaitu dana infak/sedekah yang pada saat penerimaan tidak diberikan batasanbatasan terhadap penggunaan dana tersebut.

b) Penyaluran dana infak/sedekah:

(1) Infak/sedekah terikat (muqayyadah), yaitu penyaluran dana infak/sedekah sesuai batasan-batasan yang diberikan pada saat penerimaan dana infak/sedekah.

(2) Infak/sedekah tidak terikat (mutlaqah), yaitu penyaluran dana infak/sedekah tanpa adanya batasan-batasan seperti kepada siapa dana infak/sedekah tersebut harus disalurkan.

c) Saldo awal dana infak/sedekah, yaitu jumlah dana infak/sedekah pada saat awal periode.

d) Saldo akhir dana infak/sedekah, yaitu jumlah dana infak/sedekah pada saat akhir periode.
3) Dana amil

a) Penerimaan dana amil, yaitu dana yang diperuntukkan untuk amil.

(1) Bagian dari dana zakat

(2) Bagian dari dana infak/sedekah

(3) Penerimaan lain

b) Penggunaan dana amil, yaitu dana yang digunakan untuk pengelolaan amil.

c) Saldo awal dana amil, yaitu jumlah dana amil pada saat awal periode.

d) Saldo akhir dana amil, yaitu jumlah dana amil pada saat akhir periode.

4) Dana nonhalal

a) Penerimaan dana nonhalal

(1) Bunga bank, yaitu dana yang didapat dari bunga bank.

(2) Jasa giro, yaitu dana yang didapat dari jasa giro.

(3) Penerimaan nonhalal lainnya

b) Penyaluran dana nonhalal

c) Saldo awal dana nonhalal

d) Saldo akhir dana nonhalal

\section{c. Laporan Perubahan Aset Kelolaan}

Dalam laporan perubahan aset kelolaan disajikan perubahan jumlah dan nilai aset kelolaan selama satu periode. Perubahan saldo aset kelolaan pada laporan perubahan aset kelolaan akan terlihat pada akun yang tampak pada laporan posisi keuangan dan laporan perubahan dana. Entitas amil menyajikan laporan perubahan aset kelolaan yang mencakup tetapi tidak terbatas pada:

1) Aset kelolaan yang termasuk aset lancar, menunjukkan aset kelolaan yang termasuk aset lancar yang dimiliki amil zakat. Contohnya, piutang bergulir.

2) Aset kelolaan yang termasuk tidak lancar dan akumulasi penyusutan, menunjukkan aset kelolaan yang termasuk tidak lancar yang dimiliki amil zakat. Contohya, rumah sakit atau sekolah.

3) Penambahan dan pengurangan, menunjukkan pengaruh transaksi ataupun peristiwa lainnya apabila mempengaruhi saldo aset kelolaan.

4) Saldo awal, menunjukkan jumlah aset kelolaan dari periode sebelumnya.

5) Saldo akhir, menunjukkan jumlah aset kelolaan pada saat akhir periode. 


\section{d. Laporan Arus Kas}

Laporan arus kas merupakan laporan yang menunjukkan arus kas masuk dan arus kas keluar di perusahaan. Arus kas masuk berupa pendapatan atau pinjaman dari pihak lain, sedangkan arus kas keluar merupakan biaya-biaya yang telah dikeluarkan perusahaan. Baik arus kas masuk maupun arus kas keluar dibuat untuk periode tertentu. Amil menyajikan laporan arus kas sesuai dengan PSAK 2: Laporan arus Kas melaporkan arus kas selama periode tertentu dan diklasifikasikan menjadi beberapa aktivitas, yaitu :

1) Arus Kas dari Aktivitas Operasi

Akun-akun yang disajikan adalah penambahan dan pengurangan arus kas yang terjadi pada perkiraan yang terkait dengan operasional BAZNAS seperti pendapatan (dana akat dan dana non halal), penyaluran program, dan untuk penyaluran pajak.

2) Arus Kas dari Aktivitas Investasi

Akun-akun yang termasuk dalam perkiraan ini adalah semua penerimaan dan pengeluaran yang terkait dengan investasi BAZNAS.

3) Arus Kas dari Aktivitas Pendanaan

Perkiraan yang termasuk dalam aktivitas pendanaan adalah perkiraan penerimaan dari aktivitas pencarian dana.

\section{e. Catatan Atas Laporan Keuangan.}

Catatan atas laporan keuangan merupakan laporan yang dibuat berkaitan denganlaporan keuangan yang disajikan. Laporan ini memberikan informasi tentang penjelasan yang dianggap perlu atas laporan keuangan yang ada sehingga menjadi jelas penyebabnya.Tujuan atas catatan atas laporan keuangan adalah untuk menyediakan informasi bagi para pengguna laporan keuangan mengenai:

1) Gambaran umum amil zakat

2) Ikhtisar kebijakan akuntansi yang digunakan dalam penyusunan laporan keuangan

3) Penjelasan atas pos-pos yang dianggap penting yang terdapat dalam setiap komponen laporan keuangan

4) Rasio-rasio keuangan

5) Pengungkapan hal-hal penting lainnya yang berguna untuk pengambilan keputusan.

\section{METODE PENELITIAN}

Jenis penelitian yang digunakan penulis dalam penelitian ini adalah penelitian terapan. Penelitian terapan atau applied research merupakan penelitian yang dilakukan berkenaan dengan kenyataankenyataan praktis serta pengembangan ilmu pengetahuan yang dihasilkan oleh penelitian dasar dalam kehidupan nyata. Penelitian terapan berfungsi untuk mencari solusi tentang masalah-masalah tertentu. Adapun tujuan utama dari penelitian terapan ini adalah memecahkan masalah sehingga hasil penelitian apat dimanfaatkan untuk kepentingan manusia baik secara inividu maupun kelompok.

Penelitian ini menggunakan pendekatan pendekatan kualitatif. Penelitian kualitatif merupakan suatu penelitian yang ditujukan untuk mendeskripsikan serta menganalisis suatu fenomena, aktivitas sosial, maupun pemikiran seseorang baik secara individu maupun kelompok. Selain itu penelitian kualitatif bermaksud untuk memahami fenomena tentang apa yang dialami oleh subjek penelitian seperti perilaku, persepsi, motivasi dan lain sebagainya.

Penelitian mengenai Analisis Penyusunan Laporan Keuangan Lembaga Amil Zakat Magelang Berdasarkan PSAK 109 dilakukan di BAZNAS Kabupaten Magelang yang beralamat di JL.Soekarno-Hatta, Kota Mungkid Magelang Jawa Tengah.

\section{HASIL DAN PEMBAHASAN}

\subsection{Hasil Penelitian}

\section{Pedoman PSAK 109}

\section{a. Penerimaan Zakat dan Infak/sedekah}

Penerimaan zakat diakui pada saat kas atau asset non kas diterima zakat yang diterima dari muzaki diakui sebagai penambah dana zakat sebesar :

1) Jumlah yang diterima, jika dalam bentuk kas

2) Nilai wajar jika dalam bentuk non kas

\section{b. Penyaluran Zakat Infak/sedekah}

1) Infak/sedekah yang diterima diakui sebagai dana infak/sedekah terikat atau tidak terikat sesuai dengan tujuan pemberi infak/sedekah sebesar:

a) Jumlah yang diterima, jika dalam bentuk kas

b) Nilai wajar, jika dalam bentuk nonkas.

2) Zakat yang disalurkan kepada mustahiq diakui sebagai pengurang dana zakat sebesar

a) Jumlah yang diserahkan, jika dalam bentuk kas

b) Jumlah tercatat, jika dalam bentuk aset nonkas. 
3) Penyaluran dana infak/sedekah diakui sebagai pengurang dana infak/sedekah sebesar:

a) Jumlah yang diserahkan, jika dalam bentuk kas

b) Nilai tercatat aset yang diserahkan, jika dalam bentuk aset nonkas.

4) Efektifitas dan efisiensi pengelolaan zakat bergantung pada profesionalisme amil. Dalam konteks ini amil berhak mengambil bagain dari zakat untuk menutup biaya operasional dalam rangka melaksanakan fungsinya sesuai dengan kaidah atau prinsip Syariah dan tata kelola organisasi yang baik

5) Penentuan jumlah atau persentase bagian untuk masing-masing mustahik ditentukan oleh amil sesuai dengan prinsip Syariah, kewajaran, etika dan ketentuan yang berlaku yang dituangkan dalam kebijakan amil

6) Bagian dana zakat yang disalurkan untuk amil diakui sebagai penambah dana amil.

\section{c. Penyajian ZakatInfak/sedekah}

Amil menyajikan dana zakat, dana infak/ sedekah, dana amil, dan dana nonhalal secara terpisah dalam neraca (laporan posisi keuangan).

\section{d. Pengungkapan Zakat Infak/sedekah}

1) Kebijakan penyaluran zakat, seperti penentuan skala prioritas penyaluran, dan penerima

2) Kebijaka pembagian antara dana amil dan dana nonamil atas penerimaan zakat, seperti persentase pembagian, alasan, dan konsistensi kebijakan

3) Metode penentuan nilai wajar yang digunakan untuk penerimaan zakat berupa aset nonkas

4) Rincian jumlah penyaluran dana zakat yang mencakup jumlah beban pengelolaan dan jumlah dana yang diterima langsung mustahik

5) Hubungan istimewa antara amil dan mustahiq yang meliputi : sifat hubungan istimewa, jumlah dan jenis aset yang disalurkan, presentase dari aset yang disalurkan tersebut dari total penyaluran selama periode.

\section{Akuntansi Zakat, Infak/Sedekah Pada BAZNAS Kabupaten Magelang}

BAZNAS Kabupaten Magelangmembuat laporan keuangan secara berkala setiap satu tahun sekali, Dalam pembuatan laporan keuangan BAZNAS Kabupaten Magelang mulai menerapkan
PSAK 109 tahun ini Proses akuntansi yang dilakukan oleh BAZNAS Kabupaten Magelang :

a. Membuat Rencana Kerja Anggaran Tahunan (RKAT) RKAT ini merupakan kumpulan dari seluruh program yang ada di BAZNAS Kabupaten Magelang beserta anggarannya. Divisi program adalah divisi yang memiliki kewenangan untuk membuat RKAT ini. Seminggu sebelum program dilaksanakan divisi program akan mengajukan anggaran yang dibutuhkan kepada bagian keuangan.

b. Membuat Buku Kas Zakat Buku kas zakat merupakan catatan transaksi sederhana yang menjelaskan penerimaan dan pengeluaran dana zakat.

c. Membuat Buku Kas Amil Buku kas amil hanya memuat transaksi terbatas pada amil, seperti gaji karyawan, dan operasional amil yang mencakup tunjangan kesehatan dan acara rekreasi untuk karyawan yang bersifat insidental. Format pada buku kas amil sama dengan format pada buku kas zakat dan buku kas infak/sedekah. Pada buku kas amil harus ada persetujuan dari ketua LAZIS sebagai bentuk pertanggungjawaban. Keterangan pada buku kas amil yaitu gaji pengelola sejumlah akumulasi dari seluruh gaji karyawan.

\section{Membuat Buku Kas Bank}

Format buku kas bank sama dengan buku rekening bank. Transaksi yang biasanya terjadi berupa penarikan tunai, setoran kliring, setoran cek, dan setoran tunai.

\section{Laporan Sumber dan Penggunaan Dana}

Laporan ini merupakan rekapitulasi dari buku kas zakat dan buku kas infak/sedekah yang telah dibuat sebelumnya.Laporan tersebut diterbitkan dalam buletin dan dibagikan. Laporan sumber dan penggunaan dana menjelaskan tentang pemasukan, penyaluran, dan pendayagunaan. Pemasukan merupakan dana seluruhnya yang didapat oleh BAZNAS Kabupaten Magelang. Saldo bulan sebelumnya bersumber dari sisa saldo bulan sebelumnya yang masih dimiliki oleh BAZNAS Kabupaten Magelang.

Penerimaan ZIS bersumber dari dana zakat, infak/sedekah yang diterima melalui pegawai daerah, SKPD, pengusaha dan individu yang melakukan pembayaran lewat UPZ masing-masing lembaga kemudian di transfer ke rekening BAZNAS melalui 
bank BAPAS 69 ataupun datang langsung ke kantor BAZNAS Kabupaten Magelang.Penerimaan dana ZIS pada tahun 2019 adalah Rp 2.452.171.836,sedangkan pada tahun 2018 adalah $\mathrm{Rp} \mathrm{Rp}$ 2.309.209.061,-. Apabila dibandingkan dengan tahun sebelumnya, penerimaan dana ZIS meningkat sebesar $8,96 \%$. Hal ini merupakan hasil dari kerjasama yang baik antara pelaksana bidang pengumpulan dan pendayagunaan serta para muzakki SKPD dan Dinas Instansi Vertikal di Kab. Magelang. Pada tahun 2019, BAZNAS Kab. Magelang juga memperoleh dana APBD sebesar Rp 250.000.000,-, yang merupakan bentuk perhatian dan dukungan penuh dari pemerintah daerah Kabupaten Magelang terhadap optimalisasi pengelolaan zakat di Kab. Magelang khususnya di tahun 2019. Jadi, jumlah penerimaan dana BAZNAS Kab. Magelang yang berasal dari dana ZIS dan APBD adalah Rp 2.702.171.836,-.

Penyaluran dan pendayagunaan BAZNAS menyajikan yang berkaitan dengan penyaluran untuk program kerja dan pendayagunaan untuk kegiatan BAZNAS.Dana zakat disalurkan untuk program kerja yang telah dibuat sesuai dengan asnafnya. Asnaf adalah orang yang berhak menerima zakat. Pertama asnaf fakir dan miskin, disalurkan untuk program bantuan yang bersifat konsumtif, alat kesehatan dan berobat, bantuan pendidikan, beasiswa, RTLH, bencana alamdan bantuan untuk modal usaha serta ketrampilan. Asnaf yang kedua adalah amil. Amil adalah entitas pengelola zakat yang berarti adalah BAZNAS Kabupaten Magelang. Dana yang disalurkan untuk amil dibagi menjadi dua yaitu untuk gaji dan operasional amil. Asnaf fisabilillah yaitu orang yang berjuang di jalan Allah. Dana ini disalurkan untuk program kerja bantuan sarpras tempat ibadah, bantuan sarpras lembaga pendidikan, bantuan sarpras TPQ, Ponpes dan yayasan muslim dan banyuan kegiatan lembaga keagamaan. Penyaluran selanjuatnya yaitu kepada muallaf, dana ini disalurkan untuk program kerja pembekalan agama.

Dana yang ditasarufkan selama tahun 2019 adalah Rp 1.937.555.227,-- sedangkan sisa dana ZIS akan diposkan untuk persiapan pentasarufan pada Bulan Muharram dan Ramadhan selanjutnya. Terdapat 13 kegiatan kerja BAZNAS Kab. Magelang yang telah terealisasi oleh di tahun 2019, Penerimaan dana ZIS pada tahun 2019 adalah Rp 2.452.171.836, yang artinya terjadi kenaikan penerimaan dana ZIS tahun 2019 BAZNAS Kab. Magelang 8,96\% apabila dibandingkan penerimaan ZIS tahun 2018.

Adanya hibah APBD dari Pemerintah Daerah Kabupaten Magelang sejumlah Rp 250.000.000,sebagai penunjang operasional, Pentasarufan diberikan kepada 5 asnaf yaitu fakir, miskin, amil, muallaf, dan sabilillah, Dana ZIS yang ditasarufkan BAZNAS Kab. Magelang pada tahun 2019 adalah Rp 1.937.555.227,-- sedangkan sisa dana ZIS akan diposkan untuk persiapan pentasarufan pada Bulan Muharram dan Ramadhan selanjutnya.

\section{Pengakuan dan Pengukuran Akuntansi BAZNAS Kabupaten Magelang}

Pengakuan dana zakat, infak/sedekah diakui pada saat BAZNAS Kabupaten Magelang menerima kas dan pada saat mengeluarkan kas. Pada saat pengakuan dan penyaluran maka pengukuran dapat dilakukan. Penerimaan zakat, infak/sedekah merupakan penerimaan dari potongan gaji pegawai pemerintah, PNS , pengusaha Kabupaten Magelang. Pemotongan gaji akan dilakukan oleh bagian keuangan masing masing lembaga atau UPZ kemudian mentransfer ke BAZNAS melalui rekening BAPAS 69. Dana zakat diberikan untuk lima asnaf yang telah diatur dalam hukum zakat yaitu :

a. Fakir miskin

Adapun pentasarufan asnaf Fakir Miskin berdasarkan program BAZNAS Kab. Magelang yaitu Bantuan yang bersifat Konsumtif, Bantuan alat kesehatan dan berobat, Bantuan Pendidikan.

Beasiswa pendidikan bagi yatim piatu miskin, Bantuan untuk RTLH, Bantuan Bencana Alam, Batuan Modal Usaha dan Keterampilan

b. Muallaf

Adapun pentasarufan asnaf muallaf berdasarkan program BAZNAS Kab. Magelang yaitu Pembekalan Agama kepada muallaf.

c. Sabilillah

Adapun pentasarufan asnaf sabilillah berdasarkan program BAZNAS Kab. Magelang yaitu Bantuan Sarpras tempat ibadah (masjid dan musola), Bantuan Sarpras lembaga pendidikan (PAUD, TK, MI, MTs), Santunan kepada Imam Masjid, Bantuan Sarpras TPQ, Ponpes, dan Yayasan Muslim , Bantuan Kegiatan pada Lembaga Keagamaan

\section{d. Amil}

Pentasarufan operasional amil diatur dalam Perbaznas No. 1 tahun 2016 pasal 6. Pentasarufan amil berdasarkan fungsi koordinator dan operator. 


\section{Jurnal Akuntansi dan Pajak, 21 (01), 2020, 171}

Fungsi koordinator meliputi kegiatan pelaporan dan pertanggungjawaban pelaksanaan pengelolaan Zakat nasional; pemberian pertimbangan unsur pimpinan dan kelembagaan BAZNAS Provinsi dan BAZNAS Kabupaten/Kota, pemberian rekomendasi izin pembentukan LAZ dan pembukaan perwakilan LAZ, penyusunan pedoman pengelolaan Zakat nasional, dan pengesahan penggunaan besaran Hak Amil BAZNAS Provinsi dan BAZNAS Kabupaten/Kota. Sedangkan fungsi operator meliputi pengumpulan dan penyaluran zakat.

\section{Penyajian Akuntansi BAZNAS Kabupaten Magelang}

BAZNAS Kabupaten Magelangmenyajikan laporan berupa laporan arus kas, neraca, laporan perubahan aset kelolaan, laporan perubahan dana dan laporan aset kelolaan.

a. Saldo Desember 2019

Saldo Desember 2019 merupakan hasil pengurangan dari pemasukan dan total penyaluran dan pendayagunaan pada periode Januari-Desember 2019. Saldo pada akhir periode sebesar Rp. 1.640.771.339.

b. Penerimaan ZIS

Total penerimaan dana zakat, infak/sedekah sebesar Rp 2.452.171.836,-. Hal ini merupakan hasil dari kerjasama yang baik antara pelaksana bidang pengumpulan dan pendayagunaan serta para muzakki SKPD dan Dinas Instansi Vertikal di Kab. Magelang dengan metode transfer melalui BAPAS 69 atau datang langsung ke kantor BAZNAS Kabupaten Magelang.

c. Penyaluran Dana ZIS

BAZNAS Kab. Magelang menyalurkan bantuan kepada orang yang berhak menerima zakat (asnaf). Berikut golongan asnaf adalah fakir, miskin, amil, muallaf, gharim, riqob, sabilillah, dan ibnu sabil. Selain ditasarufkan berdasarkan asnaf, BAZNAS Kab. Magelang juga memiliki program kerja di bidang pendidikan, ekonomi, kemanusiaan, kesehatan, dan dakwah-advokasi. Jumlah penyaluran dana zakat secara keseluruhan sebesar Rp. 1.894.424.248,-

Adapun penyaluranya yaitu :

1) Fakir Miskin

Penyaluran untuk fakir miskin yang paling besar dibandingkan asnaf lainnya dikarenakan sasaran BAZNAS Kabupaten Magelang adalah yang tidak mampu. Total penyaluran untuk asnaf fakir miskin sebesar Rp 1.182.785.000,- yang digunakan untuk program:

a) Santunan Kepada Fakir Miskin di Bulan Ramadhan sebesar Rp.360.600.000

b) Alat Kesehatan dan Berobat sebesar Rp. 18.000 .000

c) Bantuan untuk Biaya Pendidikan sebesar Rp.101.500.000

d) Beasiswa Pendidikan bagi Yatim Piatu sebesar Rp.659.500.000

e) Bantuan untuk Rumah Tidak Layak Huni sebesar Rp.12.000.000

f) Bantuan Bencana Alamsebesar Rp.16.200.000

g) Bantuan Modal Usaha dan Keterampilan sebesar Rp.14.985.000

2) Amil

Total penyaluran dan pendayagunaan untuk asnaf amil sebesar Rp .243.531.727,-yang digunakan untuk keperluan:

a) Biaya Rapat Pleno Rutin sebesar $\quad \mathrm{Rp}$ .38 .520 .000

b) Biaya Perjalanan Dinas sebesar Rp .39.000.000

c) Fotocopy sebesar Rp .3.300.000

d) Pentasarufan Amil sebesar Rp .87.188.727

e) Kerumahtanggaan sebesar Rp.2.158.000

f) Transpot dan BBM sebesar Rp .14.780.000

g) WiFi sebesar Rp .4.710.000

h) Biaya Alat Kebersihan sebesar Rp .4.900.000

i) PDAM sebesar Rp .560 .000

j) Dana Sosial sebesar Rp .11.050.000

k) Pajak Kendaraan BAZNAS sebesar Rp .2 .690 .000

1) ATK sebesar Rp .6.125.000

m) Biaya Seminar/Workshop/Pelatihan/Luar Kota sebesar Rp.5.500.000

n) Pengadaan Seragam BAZNAS sebesar Rp .10 .850 .000

o) Publikasi sebesar Rp .2.200.000

3) Sabilillah

Beberapa program ditujukan untuk asnaf ini namun program lebih sedikit dibandingkan asnaf fakir miskin. Total penyaluran dan pendayagunaan asnaf fisabilillah sebesar Rp. 348.988.500,- dan digunakan untuk:

a) Bantuan Sarpras tempat ibadah (masjid dan musola) sebesar Rp.170.000.000

b) Bantuan Sarpras lembaga pendidikan (PAUD, TK,MI,MTS) sebesar Rp.36.500.000 
Jurnal Akuntansi dan Pajak, 21 (01), 2020, 172

c) Santunan kepada Imam Masjid sebesar Rp.5.500.000

d) Bantuan Sarpras TPQ, Ponpes, dan Yayasan Muslim sebesar Rp.26.000.000

e) Bantuan Kegiatan pada Lembaga Keagamaan sebesarRp.110.988.500

4) Muallaf

Total penyaluran dan pendayagunaan untuk muallaf sebesar Rp.62.250.000 yang digunakan untuk Pembekalan Agama kepada Muallaf dan Bantuan Alat Solat serta Al Qur'an.

\section{Pengungkapan Akuntansi BAZNAS Kabupaten Magelang}

Pengungkapan dalam akuntansi dapat dilakukan ketika suatu lembaga membuat laporan keuangan secara lengkap. BAZNAS Kabupaten Magelang membuat laporan berupa laporan arus kas, neraca, laporan perubahan aset kelolaan, laporan perubahan dana dan laporan aset kelolaan.

\subsection{Pembahasan}

\section{Kesesuaian Laporan Keuangan BAZNAS Kabupaten Magelang dengan PSAK 109}

\begin{tabular}{|c|c|c|c|}
\hline Ket & PSAK 109 & $\begin{array}{l}\text { BAZNAS } \\
\text { Kab. } \\
\text { Magelang }\end{array}$ & $\begin{array}{l}\text { Keses } \\
\text { uaian }\end{array}$ \\
\hline $\begin{array}{l}\text { Paragraf } \\
10 \text { dan } 11\end{array}$ & $\begin{array}{l}\text { Penerimaan } \\
\text { zakat diakui } \\
\text { pada saat kas } \\
\text { atau asset non } \\
\text { kas diterima } \\
\text { zakat yang } \\
\text { diterima dari } \\
\text { muzaki diakui } \\
\text { sebagai } \\
\text { penambah } \\
\text { dana zakat } \\
\text { sebesar } \\
\text { jumlah yang } \\
\text { diterima, jika } \\
\text { dalam bentuk } \\
\text { kas dan nilai } \\
\begin{array}{l}\text { wajar jika } \\
\text { dalam bentuk } \\
\text { non kas }\end{array}\end{array}$ & $\begin{array}{l}\text { Penerimaan } \\
\text { dana zakat } \\
\text { yang telah } \\
\text { diterima } \\
\text { diakui } \\
\text { sebagai } \\
\text { penambah } \\
\text { dana zakat } \\
\text { pada saat } \\
\text { zakat } \\
\text { diterima }\end{array}$ & $\begin{array}{l}\text { Sesuai } \\
\text { PSAK } \\
109\end{array}$ \\
\hline $\begin{array}{l}\text { Paragraf } \\
24\end{array}$ & $\begin{array}{l}\text { Infak/sedekah } \\
\text { yang diterima } \\
\text { diakui sebagai } \\
\text { dana } \\
\text { infak/sedekah }\end{array}$ & $\begin{array}{l}\text { Penerimaan } \\
\text { dana zakat } \\
\text { yang telah } \\
\text { diterima } \\
\text { diakui }\end{array}$ & $\begin{array}{l}\text { Sesuai } \\
\text { PSAK } \\
109\end{array}$ \\
\hline
\end{tabular}

\begin{tabular}{|c|c|c|c|}
\hline Ket & PSAK 109 & $\begin{array}{l}\text { BAZNAS } \\
\text { Kab. } \\
\text { Magelang }\end{array}$ & $\begin{array}{l}\text { Keses } \\
\text { uaian }\end{array}$ \\
\hline & $\begin{array}{l}\text { terikat atau } \\
\text { tidak terikat } \\
\text { sesuai dengan } \\
\text { tujuan pemberi } \\
\text { infak/sedekah } \\
\text { sebesar: } \\
\text { (a) jumlah } \\
\text { yang diterima, } \\
\text { jika dalam } \\
\text { bentuk kas; } \\
\text { (b) nilai wajar, } \\
\text { jika dalam } \\
\text { bentuk nonkas. }\end{array}$ & $\begin{array}{l}\text { sebagai } \\
\text { penambah } \\
\text { dana } \\
\text { infak/sedeka } \\
\text { h pada saat } \\
\text { zakat } \\
\text { diterima }\end{array}$ & \\
\hline $\begin{array}{l}\text { Paragraf } \\
16\end{array}$ & $\begin{array}{l}\text { Zakat yang } \\
\text { disalurkan } \\
\text { kepada } \\
\text { mustahiq } \\
\text { diakui sebagai } \\
\text { pengurang } \\
\text { dana zakat } \\
\text { sebesar: } \\
\text { (a) jumlah } \\
\text { yang diserahkan, } \\
\text { jika dalam } \\
\text { bentuk kas; } \\
\text { (b) jumlah } \\
\text { tercatat, jika } \\
\text { dalam bentuk } \\
\text { aset nonkas. }\end{array}$ & $\begin{array}{l}\text { Dana zakat } \\
\text { yang telah } \\
\text { disalurkan } \\
\text { diakui } \\
\text { sebagai } \\
\text { pengurang } \\
\text { dana zakat } \\
\text { pada saat kas } \\
\text { dikeluarkan }\end{array}$ & $\begin{array}{l}\text { Sesuai } \\
\text { PSAK } \\
109\end{array}$ \\
\hline $\begin{array}{l}\text { Paragraf } \\
33\end{array}$ & $\begin{array}{l}\text { Penyaluran } \\
\text { dana } \\
\text { infak/sedekah } \\
\text { diakui sebagai } \\
\text { pengurang } \\
\text { dana } \\
\text { infak/sedekah } \\
\text { sebesar: } \\
\text { (a) jumlah } \\
\text { yang diserahkan, } \\
\text { jika dalam } \\
\text { bentuk kas; } \\
\text { (b) nilai } \\
\text { tercatat aset } \\
\text { yang diserahkan, } \\
\text { jika dalam } \\
\text { bentuk aset } \\
\text { nonkas. }\end{array}$ & $\begin{array}{l}\text { Dana } \\
\text { infak/sedeka } \\
\text { h yang telah } \\
\text { disalurkan } \\
\text { diakui } \\
\text { sebagai } \\
\text { pengurang } \\
\text { dana } \\
\text { infak/sedeka } \\
\text { h pada saat } \\
\text { kas } \\
\text { dikeluarkan }\end{array}$ & $\begin{array}{l}\text { Sesuai } \\
\text { PSAK } \\
109\end{array}$ \\
\hline Paragraf & efektifitas dan & Amil & Sesuai \\
\hline
\end{tabular}




\begin{tabular}{|c|c|c|c|c|c|c|c|}
\hline \multicolumn{8}{|c|}{ Jurnal Akuntansi dan Pajak, 21 (01), 2020, 173} \\
\hline Ket & PSAK 109 & $\begin{array}{l}\text { BAZNAS } \\
\text { Kab. } \\
\text { Magelang }\end{array}$ & $\begin{array}{l}\text { Keses } \\
\text { uaian }\end{array}$ & Ket & PSAK 109 & $\begin{array}{l}\text { BAZNAS } \\
\text { Kab. } \\
\text { Magelang }\end{array}$ & $\begin{array}{l}\text { Keses } \\
\text { uaian }\end{array}$ \\
\hline \multirow[t]{2}{*}{17} & \multirow{2}{*}{$\begin{array}{l}\text { efisiensi } \\
\text { pengelolaan } \\
\text { zakat } \\
\text { bergantung } \\
\text { pada } \\
\text { profesionalism } \\
\text { e amil. Dalam } \\
\text { konteks ini } \\
\text { amil berhak } \\
\text { mengambil } \\
\text { bagain dari } \\
\text { zakat untuk } \\
\text { menutup biaya } \\
\text { operasional } \\
\text { dalam rangka } \\
\text { melaksanakan } \\
\text { fungsinya } \\
\text { sesuai dengan } \\
\text { kaidah atau } \\
\text { prinsip Syariah } \\
\text { dan tata kelola } \\
\text { organisasi } \\
\text { yang baik }\end{array}$} & \multirow{2}{*}{$\begin{array}{l}\text { BAZNAS } \\
\text { kabupaten } \\
\text { Magelang } \\
\text { bekerja } \\
\text { professional } \\
\text { dalam rangka } \\
\text { melaksanaka } \\
\mathrm{n} \text { fungsinya } \\
\text { sesuai } \\
\text { prinsip } \\
\text { Syariah, } \\
\text { bagian } \\
\text { penyaluran } \\
\text { dana zakat } \\
\text { kepada amil } \\
\text { sebesar 12,5 } \\
\% \text { dari total } \\
\text { penerimaan } \\
\text { dana zakat } \\
\text { untuk } \\
\text { operasional } \\
\text { BAZNAS } \\
\text { Kabupaten } \\
\text { Magelang }\end{array}$} & \multirow[t]{2}{*}{$\begin{array}{l}\text { PSAK } \\
109\end{array}$} & & $\begin{array}{l}\text { diakui sebagai } \\
\text { penambah } \\
\text { dana amil. }\end{array}$ & $\begin{array}{l}\text { penyaluran } \\
\text { dana zakat } \\
\text { kepada } \\
\text { mustahik } \\
\text { nonamil dan } \\
\text { telah } \\
\text { diterima oleh } \\
\text { mustahik } \\
\text { tersebut }\end{array}$ & \\
\hline & & & & \multirow[t]{2}{*}{$\begin{array}{l}\text { Paragraf } \\
38\end{array}$} & \multirow[t]{2}{*}{$\begin{array}{l}\text { Amil } \\
\text { menyajikan } \\
\text { dana zakat, } \\
\text { dana infak/ } \\
\text { sedekah, dana } \\
\text { amil, dan dana } \\
\text { nonhalal } \\
\text { secara terpisah } \\
\text { dalam neraca } \\
\text { (laporan posisi } \\
\text { keuangan). }\end{array}$} & $\begin{array}{l}\text { Dalam } \\
\text { penyajian } \\
\text { laporan } \\
\text { keuanganya } \\
\text { BAZNAS } \\
\text { Kbupaten } \\
\text { Magelang } \\
\text { menyajikan } \\
\text { setiap } \\
\text { transaksi } \\
\text { yang } \\
\text { dilakukan } \\
\text { secara } \\
\text { terpisah } \\
\text { dalam }\end{array}$ & \multirow[t]{2}{*}{$\begin{array}{l}\text { Sesuai } \\
\text { PSAK } \\
109\end{array}$} \\
\hline \multirow[t]{3}{*}{$\begin{array}{l}\text { Paragraf } \\
18\end{array}$} & \multirow{3}{*}{$\begin{array}{l}\text { Penentuan } \\
\text { jumlah atau } \\
\text { persentase } \\
\text { bagian untuk } \\
\text { masing- } \\
\text { masing } \\
\text { mustahik } \\
\text { ditentukan } \\
\text { oleh amil } \\
\text { sesuai dengan } \\
\text { prinsip } \\
\text { Syariah, } \\
\text { kewajaran, } \\
\text { etika dan } \\
\text { ketentuan yang } \\
\text { berlaku yang } \\
\text { dituangkan } \\
\text { dalam } \\
\text { kebijakan amil }\end{array}$} & \multirow{3}{*}{$\begin{array}{l}\text { BAZNAS } \\
\text { Kabupaten } \\
\text { Magelang } \\
\text { menentukan } \\
\text { bagian } \\
\text { masing- } \\
\text { masing } \\
\text { mustahik } \\
\text { disesuaikan } \\
\text { dengan } \\
\text { prinsip } \\
\text { Syariah, } \\
\text { kewajaran, } \\
\text { etika dan } \\
\text { dengan } \\
\text { sebijak- } \\
\text { bijaknya. , } \\
\text { tetapi hanya } \\
\text { menyalurkan } \\
\text { kepada } \quad 5 \\
\text { asnaf saja } \\
\text { yaitu } \\
\text { fakir,miskin, } \\
\text { muallaf } \\
\text {,sabilillah } \\
\text { dan amil }\end{array}$} & \multirow{3}{*}{$\begin{array}{l}\text { Belum } \\
\text { Sesuai } \\
\text { PSAK } \\
109\end{array}$} & & & $\begin{array}{l}\text { laporan } \\
\text { keuanganya }\end{array}$ & \\
\hline & & & & $\begin{array}{l}\text { Paragraf } \\
39\end{array}$ & $\begin{array}{l}\text { kebijakan } \\
\text { penyaluran } \\
\text { zakat, seperti } \\
\text { penentuan } \\
\text { skala prioritas } \\
\text { penyaluran, } \\
\text { dan penerima; }\end{array}$ & $\begin{array}{l}\text { BAZNAS } \\
\text { Kabupaten } \\
\text { Magelang } \\
\text { dalam } \\
\text { menyalurkan } \\
\text { dana zakat } \\
\text { memiliki } \\
\text { prioritas } \\
\text { dalam } \\
\text { menyalurkan } \\
\text { dananya } \\
\text { yaitu hanya } \\
\text { kepada fakir, } \\
\text { miskin, } \\
\text { muallaf, } \\
\text { sabilillah dan } \\
\text { amil }\end{array}$ & $\begin{array}{l}\text { Sesuai } \\
\text { PSAK } \\
109\end{array}$ \\
\hline & & & & \multirow[t]{2}{*}{$\begin{array}{l}\text { Paragraf } \\
39\end{array}$} & \multirow{2}{*}{$\begin{array}{l}\text { Kebijaka } \\
\text { pembagian } \\
\text { antara dana } \\
\text { amil dan dana } \\
\text { nonamil atas } \\
\text { penerimaan } \\
\text { zakat, seperti } \\
\text { persentase } \\
\text { pembagian, } \\
\text { alasan, dan } \\
\text { konsistensi }\end{array}$} & \multirow{2}{*}{$\begin{array}{l}\text { BAZNAS } \\
\text { Kabupaten } \\
\text { Magelang } \\
\text { mempersenta } \\
\text { sikan bagian } \\
\text { amil sesuai } \\
\text { dengan } \\
\text { syariat islam } \\
12,5 \% \text { dari } \\
\text { keseluruhan } \\
\text { penghasilan }\end{array}$} & \multirow[t]{2}{*}{$\begin{array}{l}\text { Sesuai } \\
\text { PSAK } \\
109\end{array}$} \\
\hline $\begin{array}{l}\text { Paragraf } \\
20\end{array}$ & $\begin{array}{ll}\text { bagian } & \text { dana } \\
\text { zakat yang } \\
\text { disalurkan } \\
\text { untuk amil }\end{array}$ & $\begin{array}{l}\text { Penyaluran } \\
\text { dana amil } \\
\text { dilakukan } \\
\text { setelah }\end{array}$ & $\begin{array}{l}\text { Sesuai } \\
\text { PSAK } \\
109\end{array}$ & & & & \\
\hline
\end{tabular}




\begin{tabular}{|c|c|c|c|}
\hline \multicolumn{4}{|c|}{ Jurnal Akuntansi dan } \\
\hline Ket & PSAK 109 & $\begin{array}{l}\text { BAZNAS } \\
\text { Kab. } \\
\text { Magelang }\end{array}$ & $\begin{array}{l}\text { Keses } \\
\text { uaian }\end{array}$ \\
\hline & kebijakan & $\begin{array}{l}\text { dana zakat } \\
\text { setelah } \\
\text { penyaluran } \\
\text { dana zakat }\end{array}$ & \\
\hline $\begin{array}{l}\text { Paragraf } \\
39\end{array}$ & $\begin{array}{l}\text { metode } \\
\text { penentuan } \\
\text { nilai wajar } \\
\text { yang } \\
\text { digunakan } \\
\text { untuk } \\
\text { penerimaan } \\
\text { zakat berupa } \\
\text { aset nonkas }\end{array}$ & $\begin{array}{l}\text { BAZNAS } \\
\text { Kabupaten } \\
\text { Magelang } \\
\text { melakukan } \\
\text { penerimaan } \\
\text { hanya } \\
\text { berbentuk } \\
\text { kas }\end{array}$ & $\begin{array}{l}\text { Sesuai } \\
\text { PSAK } \\
109\end{array}$ \\
\hline $\begin{array}{l}\text { Paragraf } \\
39\end{array}$ & $\begin{array}{l}\text { Rincian } \\
\text { jumlah } \\
\text { penyaluran } \\
\text { dana zakat } \\
\text { yang } \\
\text { mencakup } \\
\text { jumlah beban } \\
\text { pengelolaan } \\
\text { dan jumlah } \\
\text { dana yang } \\
\text { diterima } \\
\text { langsung } \\
\text { mustahik }\end{array}$ & $\begin{array}{l}\text { BAZNAS } \\
\text { Kabupaten } \\
\text { Magelang } \\
\text { menyajikan } \\
\text { rincian } \\
\text { penyaluran } \\
\text { dana zakat }\end{array}$ & $\begin{array}{l}\text { Sesuai } \\
\text { PSAK } \\
109\end{array}$ \\
\hline $\begin{array}{l}\text { Paragraf } \\
39\end{array}$ & $\begin{array}{l}\text { hubungan } \\
\text { istimewa } \\
\text { antara amil } \\
\text { dan mustahiq } \\
\text { yang meliputi : } \\
\text { sifat hubungan } \\
\text { istimewa, } \\
\text { jumlah dan } \\
\text { jenis aset yang } \\
\text { disalurkan, } \\
\text { presentase dari } \\
\text { aset yang } \\
\text { disalurkan } \\
\text { tersebut dari } \\
\text { total } \\
\text { penyaluran } \\
\text { selama } \\
\text { periode. }\end{array}$ & $\begin{array}{l}\text { Penerimaan } \\
\text { dana zakat } \\
\text { yang } \\
\text { diperoleh } \\
\text { BAZNAS } \\
\text { Kabupaten } \\
\text { Magelang } \\
\text { bersumber } \\
\text { dari zakat } \\
\text { pengusaha, } \\
\text { zakat pribadi, } \\
\text { zakat para } \\
\text { PNS wilayah } \\
\text { Magelang }\end{array}$ & $\begin{array}{l}\text { Sesuai } \\
\text { PSAK } \\
109\end{array}$ \\
\hline
\end{tabular}

Dari table diatas diketahui bahwa penerimaan, penyaluran, penyajian dan pengungkapan dana zakat di BAZNAS kabupaten magelang belum sepenuhnya sesuai dengan PSAK 109. Namun BAZNAS Kabupaten Magelang sudah membuat catatan atas laporan keuangan yang dijelaskan sesuai dengan transaksi yang terjadi dan dijelaskan mengenai

kebijakan-kebijakan dan prosedur dalam penerimaan dan penyaluran dana zakat dan dana infak/sedekah yang diterapkan menejemen dalam laporan keuangan di BAZNAS Kabupaten Magelang.

\section{KESIMPULAN}

Berdasarkan hasil penelitian dan pembahasan yang telah dilakukan, maka dapat diambil kesimpulan bahwa BAZNAS Kabupaten Magelang belum sepenuhnya sesuai dengan PSAK 109 dikarenakan :

a. Pengakuan dan pengukuran zakat BAZNAS Kabupaten Magelang sudah sesuai dengan PSAK 109.

b. Pengakuan dan pengukuran infak/sedekah BAZNAS Kabupaten Magelang belum sepenuhnya sesuai dengan PSAK 109.

c. Penyajian dan pengungkapan BAZNAS Kabupaten Magelang belum sesuai dengan PSAK 109.

Untuk BAZNAS Kabupaten Magelang diharapkan pembuatan laporan harian berupa jurnal yang disertai dengan bukti transaksinya dan membuat SK tentang kebijakan penyaluran zakat kepada mustahik berdasarkan pedoman Akuntansi yang berlaku yaitu PSAK 109 .

\section{REFERENSI}

Ali, Nuruddin Mhd. Zakat Sebagai Instrumen Kebijakan Fiskal. Jakarta: PT Raja Grafindo Persada, 2006.

Arief, Sartika Wati HS, Hendrik Manossoh, and Stanly W. Alexander. "Analisis Penerapan Psak No. 109 Tentang Akuntansi Zakat, Infaq/Sedekah Pada Badan Amil Zakat Nasional Kota Manado." Jurnal Riset Akuntansi Going Concern Vol 12 (2017).

Aziz, Abdul, Muhammad Azzam, and Abdul Wahab Sayyed Hawwas. Fiqh Ibadah. Jakarta: amzan, 2010.

"Exposure Draft Pernyataan Standar Akuntansi Keuangan Akuntansi Zakat Dan Infak/ Sedekah.” In Ikatan Akuntan Indonesia. Jakarta: Dewan Standar Akuntansi Keuangan Ikatan Akuntan Indonesia, 2008.

Hafiduddin, Didin. Zakat Dalam Perekonomian Modern. Jakarta: Gema Insani Press, 2002.

Harahap, Sofyan Syafri. Ekonomi Islam. Jakarta: Bumi Aksara, 2011. 
Jurnal Akuntansi dan Pajak, 21 (01), 2020, 175

Hasan, M. Ali. Zakat, Pajak, Asuransi Dan Lembaga Keuangan. Jakarta: Raja Grafindo Persada, 2000.

IAI. Pernyataan Standar Akuntasi Keuangan 109. Jakarta: Ikatan Akuntansi Indonesia, 2016.

Indonesia, Ikatan Akuntansi. Standar Akuntansi Keuangan Entitas Tanpa Akuntabilitas Publik. Jakarta: Ikatan Akuntansi Indonesia, 2016.

Jusuf, Al Haryono. Dasar- Dasar Akuntansi Jilid 2. Yogyakarta, 2001.

Kusnandar, Viva Budy. "Indonesia, Negara Dengan Penduduk Muslim Terbesar Dunia," 2019. https://databoks.katadata.co.id/datapublish/2019/ 09/25/indonesia-negara-dengan-pendudukmuslim-terbesar-dunia.

Kustiawan, Teten. Pedoman Akuntasi Zakat. Jakarta: forum zakat, 2012.

Lincolind, Soeratno dan. Metode Penelitian Untuk Ekonomi Dan Bisnis. Yogyakarta: STIM YKPN, 1993.

Moleong, Lexy J. Metode Penelitian Kualitatif. Bandung: Remaja Rosdakarya, 2012.

Muhammad. Zakat Profesi Wacana Pemikiran Dalam Fiqh Kontemporer. Jakarta: Salemba Diniyah, 2002.

Mursyidi. Akuntansi Zakat Kontemporer. Bandung: Remaja Rosda karya, 2006.

Nikmatuniyah, and Marliyati. "Akuntabilitas Laporan Keuangan Lembaga Amil Zakat Di Kota Semarang.” MIMBAR, Vol. 31, N (2015).
Qardawi, Yusuf. Hukum Zakat, Terj. Salman Harun Dkk, Cet 7. Bogor: Pustaka Lentera Antar Nusa, 2004.

Ritonga, Pandapotan. "Analisis Akuntansi Zakat Berdasarkan Psak No. 109 Pada Badan Amil Zakat Nasional (BAZNAS) Sumatera Utara." KITABAH Volume 1. (2017).

Saifuddin, Zuhri. Zakat Di Era Reformasi:Tata Kelola Baru. Semarang: Bima Sejati, 2012.

Sawarjuwono, N. H. "Kuntabilitas Pengelolaan Zakat Melalui Pendekatan Modifikasi Action Research.” ISSN vol 5 (2013).

Shahnaz, Sabrina. "Penerapan Psak No.109 Tentang Pelaporan Keuangan Akuntansi Zakat, Infaq/Sedekah Pada Badan Amil Zakat Provinsi Sulawesi Utara." Jurnal EMBA Vol.3 No.4 (2015).

Sugiyono. Metode Penelitian Pendidikan. Bandung: Alfabeta, 2016.

Sukmadinata, Nana Syaodih. Metode Penelitian Pendidikan. PT Remaja. Bandung, 2015.

Wibisono, Yusuf. Mengelola Zakat Indonesia: Dikursus Pengelolaan Zakat Nasional Dari Rezim Undang-Undang Nomor 38 Tahun 1999 Ke Rezim Undang-Undang Nomor 23 Tahun 2011. Jakarta, 2015. 